Wainwright, S. D. \& Nevill, A. (1956). J. gen. Microbiol. 14, 47-56

\title{
The Influence of Depletion of Nitrogenous Reserves upon the Phenomenon of Induced Enzyme Biosynthesis in Cells of Escherichia coli
}

\author{
By S. D. WAINWRIGHT* AND ANN NEVILL
}

Biology Branch, Atomic Energy of Canada Ltd., Chalk River, Ontario

SUMMARY: No $\beta$-galactosidase was formed when nitrogen-depleted cells of Escherichia coli 1433 were treated with lactose unless a source of nitrogen was added to the cells. In the presence of an exogenous nitrogen source there was an appreciable delay between the addition of lactose and the appearance of induced $\beta$-galactosidase activity. In contrast, induced increases of nitrate- and tetrathionate-reductase activities were developed without appreciable delay when depleted cells were treated with nitrate and tetrathionate, respectively, in the absence of additional nitrogen sources. The total amounts of the reductase activities developed in depleted cells were less than those obtained with non-depleted cells. The total amount of nitrate reductase activity formed was only slightly increased in the presence of ammonium sulphate, whereas normal degrees of activity were attained in the presence of casein hydrolysate. Ammonium sulphate markedly stimulated the formation of tetrathionate reductase activity.

Conclusive evidence has been presented (Monod \& Cohn, 1953; Hogness, Cohn \& Monod, 1955; Rotman \& Spiegelman, 1954) that under certain conditions cells of Escherichia coli do not contain appreciable amounts of complex precursors of the inducible (adaptive) $\beta$-galactosidase. Similarly, for the inducible maltozymase system of Saccharomyces cerevisiae, Halvorson $\&$ Spiegelman (1952, 1953 $a, b$; Spiegelman \& Halvorson, 1953) concluded that induced enzyme is probably not formed via complex precursors that are normally present in non-induced cells. It has, therefore, been suggested (Monod \& Cohn, 1953; Rotman \& Spiegelman, 1954) that the process of induced enzyme formation is essentially one of de novo synthesis entirely from free amino acids. However, the maltozymase system of Sacharomyces cerevisiae is unstable and can be degraded even by cells which are not depleted of nitrogen reserves (Spiegelman \& Dunn, 1947). Hence, as noted by Spiegelman \& Halvorson (1953), the information obtained to date for this system cannot be considered as critical evidence of the absence of complex enzyme precursors from the cells.

The processes of induced $\beta$-galactosidase synthesis in Escherichia coli differ in a number of respects from those of induced formation of other systems. For example, little $\beta$-galactosidase synthesis can occur in suspensions of wellwashed cells of $E$. coli (Cohn \& Torriani, 1953), whereas considerable formation of the nitrate and tetrathionate reductase (nitratase and tetrathionase)

* Atomic Energy of Canada Ltd. Fellow. Present Address : Department of Microbiology, Yale University, New Haven, Connecticut, U.S.A. 
systems can occur in such cells (Pollock, 1946). We have, therefore, compared the effects of depletion of the nitrogen reserves upon the formation of the inducible $\beta$-galactosidase and of nitrate and tetrathionate reductases by cells of $\boldsymbol{E}$. coli in order to determine whether the processes of formation of the various enzymes also differ under conditions of acute shortage of available nitrogen. Marked differences were found between the processes of synthesis of $\beta$-galactosidase and those of formation of the reductases.

\section{METHODS}

Organism and medium. All experiments were performed with the 1433 strain of Escherichia coli (Pollock, 1946).

The medium used was based upon the medium 56 of Monod, Cohen-Bazire \& Cohn (1951), but with the $\mathrm{N}$-content decreased to a growth-limiting concentration of $0.02 \%(\mathrm{w} / \mathrm{v})$ of $\left(\mathrm{NH}_{4}\right)_{2} \mathrm{SO}_{4}$. It consisted of: $\mathrm{KH}_{2} \mathrm{PO}_{4}, 13 \cdot 6 \mathrm{~g}$.; $\left(\mathrm{NH}_{4}\right)_{2} \mathrm{SO}_{4}$, $0 \cdot 2$ g.; $\mathrm{MgSO}_{4} .7 \mathrm{H}_{2} \mathrm{O}, 0.2 \mathrm{~g}$; $\mathrm{CaCl}_{2}, 0.01$ g.; $\mathrm{FeSO}_{4} .7 \mathrm{H}_{2} \mathrm{O}, 0.0005$ g.; $\mathrm{KOH}$ to $\mathrm{pH} 7 \cdot 2$ and water to $\mathrm{l}$ l. Double-distilled water was used throughout.

Preparation of cultures for induction experiments. Batches of medium were supplemented with $0.05 \%(\mathrm{w} / \mathrm{v})$ nitrogen-free maltose, inoculated and incubated aerobically at $37^{\circ}$ overnight. Additional maltose was added to a concentration of $0.5 \%(\mathrm{w} / \mathrm{v})$ and the culture re-incubated aerobically at $37^{\circ}$. Cultures were used for induction experiments $3 \mathrm{hr}$. after growth had ceased because of exhaustion of the nitrogen source.

Growth measurement. Growth was followed by measurements of optical density at a wavelength of $610 \mathrm{~m} \mu$. and the readings converted to mg. dry wt. of cell mass by means of standard curves.

$\beta$-Galactosidase adaptation. Aerobic formation of enzyme was induced in $125 \mathrm{ml}$. Erlenmeyer flasks shaken at $37^{\circ}$. Each flask contained 6 or $7 \mathrm{ml}$. of depleted culture, recrystallized lactose (Pfanstiehl C.P.) to $0 \cdot 2 \%(\mathrm{w} / \mathrm{v})$, additions and distilled water to $10 \mathrm{ml}$. After incubation for the desired period, the optical density was measured and the culture prepared for assay of enzyme activity by incubating with 2 drops of toluene at $37^{\circ}$ for $15 \mathrm{~min}$.

Anaerobic formation of the enzyme was similarly induced in evacuated Thunberg tubes, the contents being transferred to Erlenmeyer flasks for treatment with toluene.

$\beta$-Galactosidase activities were determined, at room temperature $\left(c .25^{\circ}\right)$, by the liberation of $o$-nitrophenol from $\mathrm{m} / 600 o$-nitrophenyl- $\beta$-D-galactoside (Lederberg, 1950). Activities are expressed as $\mu$ mole galactoside hydrolysed/ hr./mg. dry wt. cells. Total activities of the cultures are expressed as $\mu$ mole galactoside hydrolysed/hr./10 ml. culture.

Nitrate reductase adaptation. Nitrate reductase formation was induced in evacuated Thunberg tubes at $37^{\circ}$. Unless otherwise stated, each tube contained 6 or $7 \mathrm{ml}$. depleted culture, $1 \mathrm{ml} .0 \cdot 1 \mathrm{M}$-glucose (twice recrystallized from $80 \%(\mathrm{v} / \mathrm{v})$ ethanol), 0.5 or $1 \mathrm{ml}$. of $0.1 \mathrm{~m}$-sodium nitrate in the stopper, additions and distilled water to $10 \mathrm{ml}$. The adaptation was followed by estimations of the nitrite produced using the Griess-Ilosvay reagent (Pollock, 1946). 
The cells were spun down, washed once with distilled water and resuspended in water.

Nitrate reductase activities were determined in evacuated Thunberg tubes at $37^{\circ}$ with $0.01 \mathrm{M}$-sodium formate as $\mathrm{H}$-donor and in the presence of $\mathrm{M} / 800$ $\mathrm{FeSO}_{4}$ (Wainwright \& Pollock, 1949). Activities are expressed as $\mu$ mole nitrite produced/hr./mg. dry wt. cells. Total nitrate reductase activities of the cultures are expressed as $\mu$ mole nitrite produced $/ \mathrm{hr} . / 10 \mathrm{ml}$. culture.

Tetrathionate reductase adaptation. Tetrathionate reductase formation was induced in evacuated Thunberg tubes in the same manner as nitrate reductase, $0 \cdot 1 \mathrm{~m} \mathrm{Na}$ tetrathionate replacing the nitrate.

Tetrathionate reductase activities were determined in evacuated Thunberg tubes at $37^{\circ}$ by titration of the thiosulphate produced with $0.002 \mathrm{~N}$ iodine (Wainwright \& Pollock, 1949). Activities are expressed as $\mu$ mole thiosulphate produced $/ \mathrm{hr} . / \mathrm{mg}$. dry wt. cells. Total tetrathionate reductase activities of the cultures are expressed as $\mu$ mole of thiosulphate produced $/ \mathrm{hr} . / 10 \mathrm{ml}$. culture.

\section{RESULTS}

\section{$\beta$-Galactosidase adaptation as a control of experiments}

Cohn \& Torriani (1953) found that organisms of the ML 30 strain of Escherichia coli which had been depleted of nitrogenous reserves did not form any $\beta$-galactosidase when treated with inducer. Similarly, we found that nitrogendepleted organisms of the 1433 strain did not form any $\beta$-galactosidase when treated with lactose for periods up to $4 \mathrm{hr}$. under either aerobic or anaerobic conditions. Indeed, the enzyme activity frequently fell below the small 'basal' activity originally present. In the presence of $0.5 \%(\mathrm{w} / \mathrm{v})\left(\mathrm{NH}_{4}\right)_{2} \mathrm{SO}_{4}$ enzyme formation did occur after a lag period, which was invariably shorter under anaerobic conditions than under aerobic conditions (Fig. 1); the experiment illustrated records the shortest lag we have observed aerobically and in one experiment the lag exceeded $3 \mathrm{hr}$.

Table 1. Anaerobic formation of $\beta$-galactosidase in the presence of a low concentration of ammonium sulphate

Cultures depleted of nitrogen reserves were incubated for $2.5 \mathrm{hr}$. anaerobically at $37^{\circ}$ with $0.2 \%(\mathrm{w} / \mathrm{v})$ lactose in the absence or presence of $0.0005 \%(\mathrm{w} / \mathrm{v})\left(\mathrm{NH}_{4}\right)_{2} \mathrm{SO}_{4}$.

\begin{tabular}{|c|c|c|}
\hline $\begin{array}{l}\text { Initial } \\
\text { culture }\end{array}$ & $\begin{array}{l}\text { Without } \\
\left(\mathrm{NH}_{4}\right)_{2} \mathrm{SO}_{4}\end{array}$ & $\begin{array}{c}\text { With } \\
\left(\mathrm{NH}_{4}\right)_{2} \mathrm{SO}_{4}\end{array}$ \\
\hline $0 \cdot 10$ & 0.05 & 1.82 \\
\hline 0.22 & 0.24 & $3 \cdot 60$ \\
\hline $0 \cdot 16$ & 0.08 & $0 \cdot 18$ \\
\hline $0 \cdot 17$ & $0 \cdot 18$ & $0 \cdot 43$ \\
\hline $0 \cdot 17$ & 0.07 & $0 \cdot 68$ \\
\hline
\end{tabular}

Marked increases in $\beta$-galactosidase activity were observed after anaerobic induction in the presence of concentrations of $\left(\mathrm{NH}_{4}\right)_{2} \mathrm{SO}_{4}$ as low as $0.0005 \%$ $(\mathrm{w} / \mathrm{v}$ ) (equivalent to $1 \cdot 1 \mu \mathrm{g} . \mathrm{N} / \mathrm{ml}$.) (Table 1 ) and occasionally, but not invariably, 
with concentrations of $0.00005 \%(w / v)$. However, we never observed any increase in $\beta$-galactosidase activity after aerobic induction for $3 \mathrm{hr}$. in the presence of concentrations of $0 \cdot 0005 \%(\mathrm{w} / \mathrm{v})\left(\mathrm{NH}_{4}\right)_{2} \mathrm{SO}_{4}$ or less.
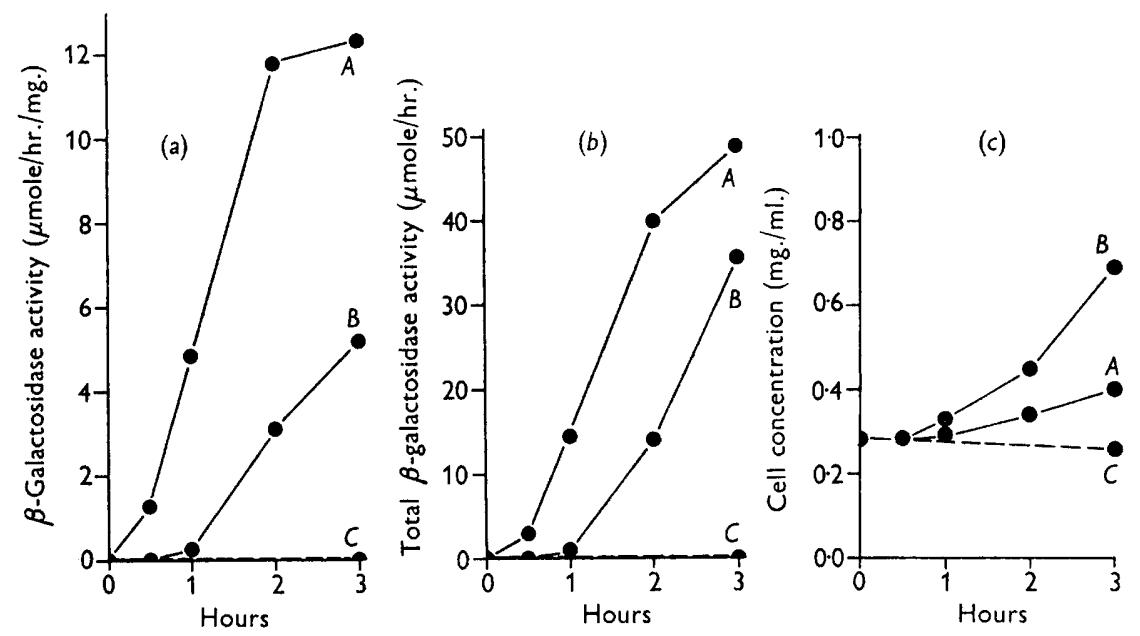

Fig. 1. Influence of $\left(\mathrm{NH}_{4}\right)_{2} \mathrm{SO}_{4}(0.5 \% \mathrm{w} / \mathrm{v})$ on aerobic and anaerobic formation of $\beta$-galactosidase by nitrogen depleted Escherichia coli 1433 induced with lactose $(0 \cdot 2 \% \mathrm{w} / \mathrm{v})$. (a) $\beta$-galactosidase activities/mg. dry wt. cells; (b) total $\beta$-galactosidase activities of cultures; $(c)$ growth curves. $A$, anaerobic induction; $B$, aerobic induction; $C$, anaerobic induction without $\left(\mathrm{NH}_{4}\right)_{2} \mathrm{SO}_{4}$.

For routine control of the depletion of the nitrogen reserves, in every experiment reported here we incubated portions of the cultures aerobically with $0 \cdot 2 \%(\mathrm{w} / \mathrm{v})$ lactose for a minimum period of $2 \mathrm{hr}$. and confirmed the absence of $\beta$-galactosidase formation. In many of the experiments we also incubated portions of the culture anaerobically with lactose as a control to confirm the absence of detectable traces of contaminating nitrogen sources.

\section{Nitrate reductase formation in nitrogen-depleted organisms}

When depleted organisms were incubated anaerobically with nitrate and glucose (as energy source) there was a rapid and marked increase in nitrate reductase activity, and the total activity of the culture rose to a maximum value within $2 \mathrm{hr}$. Fig. 2 shows the results of an experiment carried out with the same batch of depleted cells used for the experiment illustrated in Fig. 1. There was some growth during the adaptation (Fig. 2c), indicating that the cells had been supplied with a source of available nitrogen, which was identified as being produced metabolically from the inducing nitrate. As the inducing nitrate was itself serving as a source of available nitrogen, it was clearly not possible to study nitrate reductase formation in the total absence of nitrogen sources. However, it was consistently found that there was little or no lag in formation of nitrate reductase, whereas there was an appreciable delay in the onset of increase in cell mass (Fig. 2a,c). Further, growth continued at an 
undiminished rate after the maximum total nitrate reductase activity of the culture was attained, indicating that the latter was not limited by exhaustion of the source of available nitrogen. Indeed, there was little increase in the maximum total activity of the culture when $\left(\mathrm{NH}_{4}\right)_{2} \mathrm{SO}_{4}$ was added in concentrations of 0.005 (Fig. $2 b$ ), 0.05 and $0.5 \%(\mathrm{w} / \mathrm{v})$, although the initial rate of increase in enzyme activity was enhanced in every case (Fig. $2 a, b$ ).
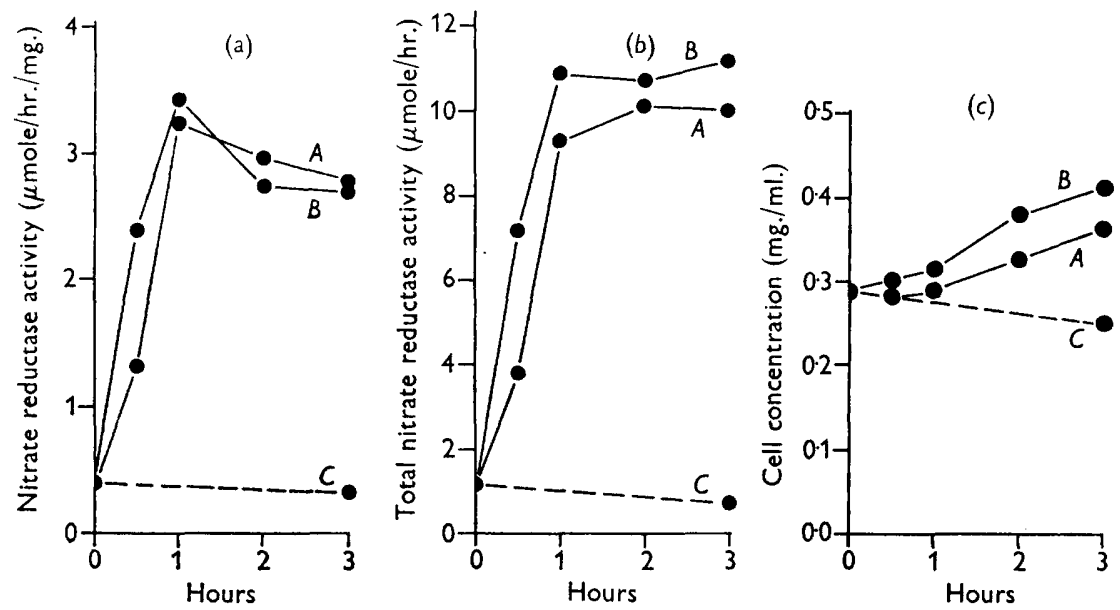

Fig. 2. Influence of $\left(\mathrm{NH}_{4}\right)_{2} \mathrm{SO}_{4}(0.005 \%, w / v)$ on nitrate reductase formation by nitrogen depleted Escherichia coli 1433 induced with nitrate $(0.01 \mathrm{M})$. (a) Nitrate reductase activities per mg. dry wt. of cells; $(b)$ total nitrate reductase activities of cultures; (c) growth curves. $A$, without $\left(\mathrm{NH}_{4}\right)_{2} \mathrm{SO}_{4} ; B$, with $\left(\mathrm{NH}_{4}\right)_{2} \mathrm{SO}_{4} ; C$, control without nitrate or $\left(\mathrm{NH}_{4}\right)_{2} \mathrm{SO}_{4}$.

Even in the presence of $\left(\mathrm{NH}_{4}\right)_{2} \mathrm{SO}_{4}$, the maximum total nitrate reductase activities attained by these cultures of depleted organisms were always considerably less than the highest (not necessarily maximum) values previously observed with cultures of undepleted organisms growing under similar conditions (Wainwright \& Pollock, 1949). It therefore seemed possible that the factor which limited the development of nitrate reductase activity by nitrogendepleted cells might be a limiting rate of de novo synthesis of amino acids. In support of such an interpretation it was found that in the presence of an acid hydrolysate of casein ('Bacto Casamino acids') there was a marked increase in the total activity of the culture (Fig. 3).

Other possible interpretations of the limited increase in nitrate reductase activity and the rapid attainment of a maximum total activity in cultures of previously depleted cells were considered. The increase in enzyme activity was totally inhibited in the presence of $40 \mu \mathrm{g}$. chloramphenicol $/ \mathrm{ml}$, indicating that the process was indeed one of protein metabolism (Gale \& Folkes, 1953, 1954; Wisseman, Smadel, Hahn \& Hopps, 1954).

Nitrite did not inhibit the increase in nitrate reductase activity when added in a concentration of $0.001 \mathrm{M}$ and was only slightly inhibitory at a concentration of $0.01 \mathrm{M}$ (the maximum concentration which could accumulate during normal 
induction). Thus, the absence of a continued rise in the total activity of the culture was not due to the accumulation of toxic concentrations of nitrite.

The induced cells showed no detectable nitrite reductase activity. Thus, the attainment of a maximum total nitrate reductase of the culture was not an artefact resulting from significant reduction of nitrite during the assays of nitrate reductase.
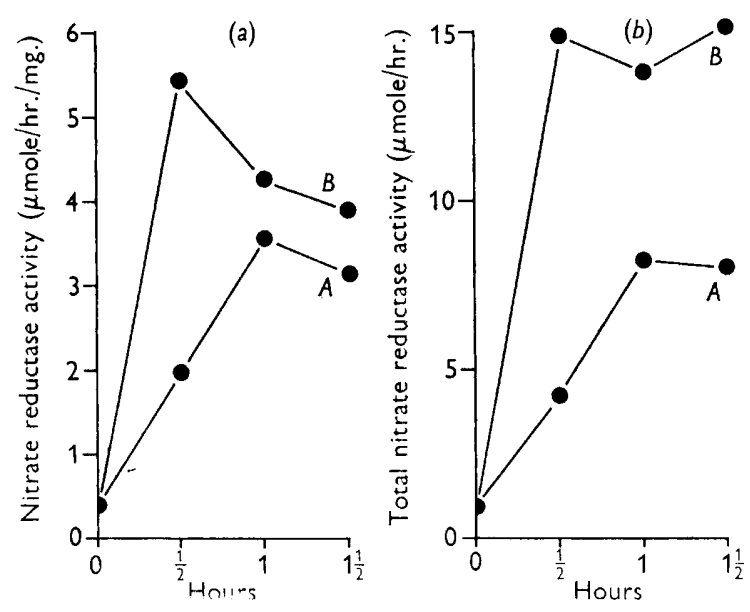

(c)

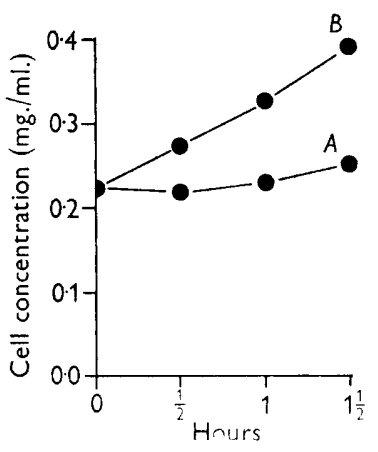

Fig. 3. Influence of casein hydrolysate $(0 \cdot 2 \%, w / v)$ on nitrate reductase formation by nitrogen depleted Escherichia coli 1433 induced with nitrate $(0.01 \mathrm{M})$. (a) Nitrate reductase activities/mg. dry wt. of cells; (b) total nitrate reductase activities of cultures; (c) growth curves. $A$, without casein hydrolysate; $B$, with casein hydrolysate.

It seemed possible that the period of depletion, though adequate to deprive the cells of some key amino acid essential for $\beta$-galactosidase formation, was inadequate to deplete all nitrogenous reserves and that more prolonged starvation would eliminate the ability to form nitrate reductase. We therefore tested the ability of the cells to form enzyme when incubated anaerobically with nitrate both before exhaustion of the nitrogen source in the parent culture and at various intervals after the cessation of growth. The results of one such experiment are given in Fig. 4. Although complex, they are very different from those to be expected if more prolonged starvation had effected a greater decrease in the amount of available endogenous nitrogen reserves. Indeed, the most significant feature of these data is the inverse correlation between the total amount of enzyme formed (Fig. $4 b$ ) and the extent of the increase in cell mass after addition of nitrate inducer (Fig. $4 c$ ).

An alternative interpretation of the early cessation of increase in total nitrate reductase activity of the culture would be that the measured enzyme activity was not limited by the amount of enzyme protein present in the cells, but by the available quantity of some other accessory factor of the system. This possibility could not be tested directly, for the enzyme system has not yet been isolated from Escherichia coli and there are reasons for believing that the system may differ from the nitrate reductase system of 
Neurospora crassa* (Nicholas \& Nason, 1954). However, the same general picture was obtained with glucose as $\mathrm{H}$-donor in the assays (at $45^{\circ}$ to prevent further adaptation) in place of formate. Yet the data of Fig. $4 b$ and $d$ indicate that the measured nitrate reductase activities of depleted cells are more likely to be affected by deficiency of co-factors when glucose is used as $\mathrm{H}$-donor, for the adaptation curves (Fig. $4 d$ ) show no indication of a progressive increase in activity with increased period of depletion.

The maximum total nitrate reductase activity of the culture was not limited by deficiencies of either iron or molybdenum.
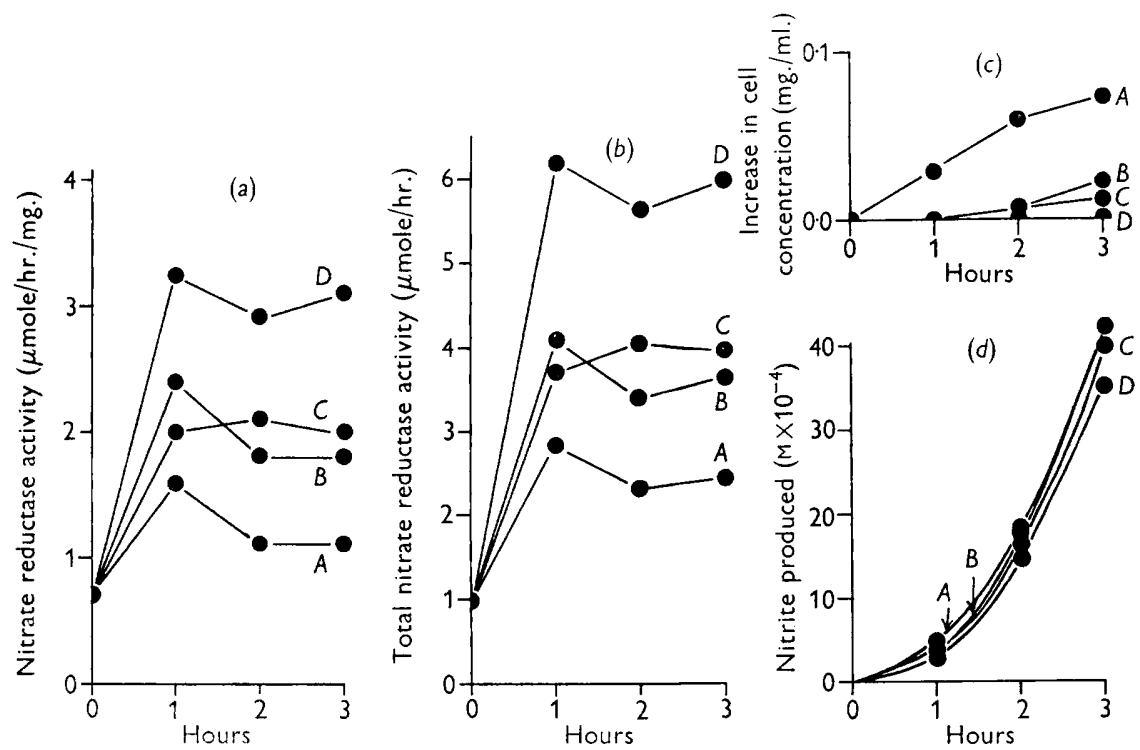

Fig. 4. Influence of duration of depletion period upon nitrate reductase formation by nitrogen depleted Escherichia coli 1433 induced with nitrate $(0 \cdot 01 \mathrm{M}) . \quad(a)$ Nitrate reductase activities/mg. dry wt. of cells; $(b)$ total nitrate reductase activities of cultures; $(c)$ growth curves (expressed as further increase during induction); $(d)$ adaptation curves. Induction: $A, 1 \frac{1}{4} \mathrm{hr}$. before exhaustion of nitrogen reserves; $B, 1 \frac{1}{2} \mathrm{hr}$.; $C, 3 \mathrm{hr}$. $D, 4 \frac{1}{2} \mathrm{hr}$. after depletion of reserves.

\section{Tetrathionate reductase adaptation in nitrogen-depleted cells}

When depleted cells were incubated anaerobically with tetrathionate and glucose (as energy source) there was a marked and immediate increase in tetrathionate reductase activity (Fig. 5). There was no increase in cell mass and, in fact, the optical density of the culture decreased slightly (Fig. $5 c$ ). The possibility of nitrogen sources being made available for enzyme synthesis by cell lysis cannot be excluded. However, the decrease in optical density, which

* Assays of crude preparations of the nitrate reductase of Escherichia coli 1433 by the method recently described by Nicholas \& Nason (1955) usually gave values less than $1 \%$ of those obtained with reduced methylene blue as $\mathbf{H}$-donor. Preliminary evidence suggests that a derivative of menodione is an essential co-factor of the enzyme (Wainwright, Biochim. biophys. Acta, in the press). 
corresponded to the lysis of $c .25 \mu \mathrm{g}$. dry wt. cells $/ \mathrm{ml}$., also occurred in all anaerobic control cultures (e.g. Fig. 1). Yet, in the presence of lactose there was no synthesis of $\beta$-galactosidase, either in the presence or absence of tetrathionate (Fig. 1). Further, tetrathionate appeared to stimulate rather than inhibit $\beta$-galactosidase formation when $\left(\mathrm{NH}_{4}\right)_{2} \mathrm{SO}_{4}$ was added in conconcentrations as small as $0.0005 \%(\mathrm{w} / \mathrm{v})$. Thus, tetrathionate reductase was formed either in the total absence of extraneous nitrogen sources, or, at least, in response to the presence of concentrations of nitrogen sources inadequate to support $\beta$-galactosidase formation. The adaptation process was markedly stimulated by the addition of $\left(\mathrm{NH}_{4}\right)_{2} \mathrm{SO}_{4}$. Chloramphenicol, at $40 \mu \mathrm{g}$. $/ \mathrm{ml}$., totally inhibited induced tetrathionate reductase formation.
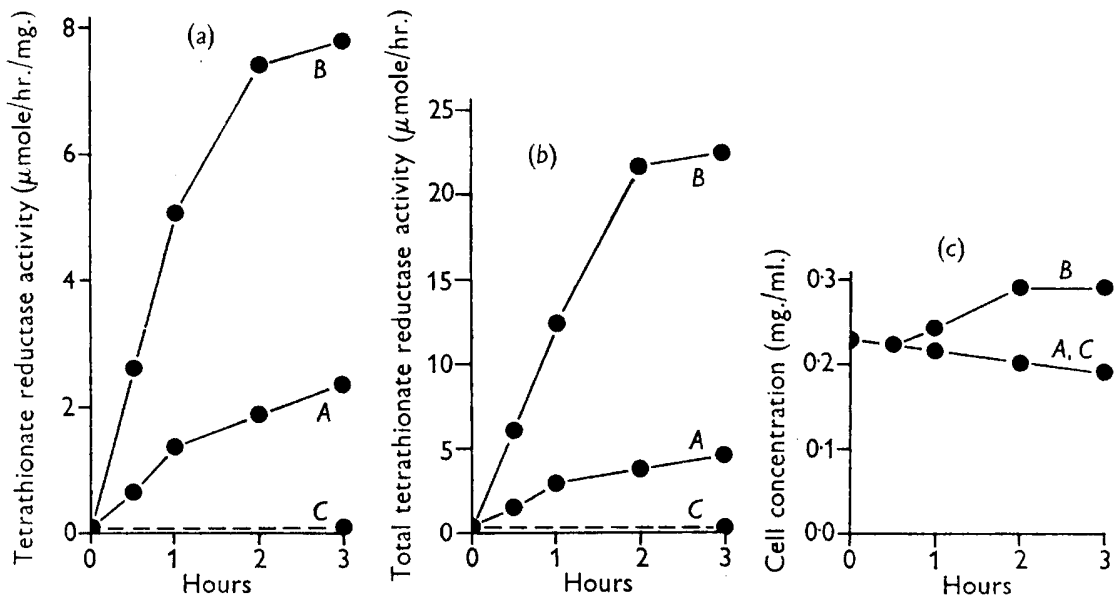

Fig. 5. Influence of $\left(\mathrm{NH}_{4}\right)_{2} \mathrm{SO}_{4}(0.005 \%, \mathrm{w} / \mathrm{v})$ on tetrathionate reductase formation by nitrogen depleted Escherichia coli 1433 induced with tetrathionate (0.01 M). (a) Tetrathionate reductase activities $/ \mathrm{mg}$. dry wt. cells; $(b)$ total tetrathionate reductase activities of cultures; $(c)$ growth curves. $A$, without $\left(\mathrm{NH}_{4}\right)_{2} \mathrm{SO}_{4} ; B$, with $\left(\mathrm{NH}_{4}\right)_{2} \mathrm{SO}_{4} ; C$, control without tetrathionate or $\left(\mathrm{NH}_{4}\right)_{2} \mathrm{SO}_{4}$.

\section{DISCUSSION}

It is clear that the nitrogen requirements for induced formation of $\beta$-galactosidase by intact organisms of Escherichia coli 1433 differ from those for formation of the nitrate and tetrathionate reductases even with a single population of organisms (e.g. Figs. 1, 2). $\beta$-Galactosidase is not produced unless an external source of nitrogen is present, and even then there is an appreciable delay between the addition of lactose inducer and the appearance of induced enzyme. Further, this delay is not related in any simple manner to the lag period in the over-all synthesis of protein (Fig. 1). In contrast, the tetrathionate reductase system is formed without appreciable delay and in the absence of detectable nitrogen sources (Fig. 5). The possibility of nitrogen sources being made available by cell lysis has not been eliminated, but the extent of lysis which occurred during induction with tetrathionate was no greater than when cells were treated anaerobically with lactose. In the case of the nitrate 
reductase system the inducing nitrate itself served as a nitrogen source. However, the absence of any appreciable lag in enzyme formation (Fig. 2) is in marked contrast to the result obtained for $\beta$-galactosidase.

These variations in nitrogen requirements may be manifestations of quantitative differences in the efficiencies with which homologous specific components of the various 'enzyme-forming systems' can compete for limiting amounts of amino acids (Wainwright, 1950). Alternatively, it seems possible that the cells can be depleted of all nitrogen sources which can serve as 'precursors' of $\beta$-galactosidase but yet contain materials which can be utilized for the synthesis of the reductases. If the latter be the case, the data obtained in this study would indicate that the process of enzyme synthesis consists of at least two phases: (1) de novo synthesis of 'precursor', which could only occur if either the depleted cells were supplied with an excess of pre-formed amino acids (Fig. 3), or if they were unable to use their own metabolic products for increase in cell mass (Fig. 4); (2) conversion of 'precursor' into active enzyme, which could occur in the presence of very low concentrations of available nitrogen source. The data do not permit discrimination between the two alternative types of interpretation. However, they do demonstrate a major difference between various 'enzyme-forming systems', at least in the intact organisms.

We are indebted to Messrs Parke Davis and Co. Ltd., Walkerville, Ontario, for a generous gift of pure chloramphenicol.

\section{REFERENCES}

Cohn, M. \& Torriani, A-M. (1953). The relationships in biosynthesis of the $\beta$-galactosidase and Pz-proteins in Escherichia coli. Biochim. biophys. Acta, 10, 280.

Gale, E. F. \& Folkes, J. P. (1953). The assimilation of amino-acids by bacteria. 15. Actions of antibiotics on nucleic acid and protein synthesis in Staphylococcus aureus. Biochem. J. 53, 493.

Gale, E. F. \& Folkes, J. P. (1954). Effect of nucleic acids on protein synthesis and amino-acid incorporation in disrupted staphylococcal cells. Nature, Lond. 173, 1223.

Halvorson, H. O. \& Spiegelman, S. (1952). The inhibition of enzyme formation by amino acid analogues. J. Bact. 64, 207 .

Halvorson, H. O. \& Spiegelman, S. (1953a). The effect of free amino acid pool levels on the induced synthesis of enzymes. J. Bact. 65, 496.

Halvorson, H. O. \& Spiegelman, S. (1953b). Net utilization of free amino acids during the induced synthesis of maltozymase in yeast. $J$. Bact. 65, 601 .

Hogness, D. S., Corn, M. \& Monod, J. (1955). Studies on the induced synthesis of $\beta$-galactosidase in Escherichia coli: The kinetics and mechanism of sulphur incorporation. Biochim. biophys. Acta, 16, 99.

Lederberg, J. (1950). The beta-D-galactosidase of Escherichia coli, strain K-12. J. Bact. 60, 381.

Monod, J., Cohen-Bazire, G. \& Cohn, M. (1951). Sur la biosynthèse de la $\beta$-galactosidase (lactase) chez Esch. coli. La spécificité de l'induction. Biochim. biophys. Acta, 7, 585.

Monod, J. \& Cohn, M. (1953). Sur le mécanisme de la synthèse d'une protéine bactérienne. La $\beta$-galactosidase d'E. coli. In Microbial Metabolism, Symp. VIth int. Congr. Microbiol. p. 42. 
Nrcholas, D. J. D. \& Nason, A. (1954). Molybdenum and nitrate reductase. II. Molybdenum as a constituent of nitrate reductase. J. biol. Chem. 207, 353.

Nicholas, D. J. D. \& Nason, A. (1955). Diphosphopyridine nucleotide-nitrate reductase from Escherichia coli. J. Bact. 69, 580.

Pollock, M. R. (1946). Adaptation of 'nitratase' in washed suspensions of bacteria. Brit. J. exp. Path. 27, 419.

Rotman, B. \& Spicgelman, S. (1954). On the origin of the carbon in the induced synthesis $\beta$-galactosidase in Escherichia coli. J. Bact. 68, 419.

Spiegelman, S. \& DunN, R. (1947). Interactions between enzyme-forming systems during adaptation. J. gen. Physiol. 31, 153.

Spiegelman, S. \& Halvorson, H. O. (1953). The nature of the precursor in the induced synthesis of enzymes. Adaptation in Micro-organisms. Third Symp. Soc. gen. Microbiol. p. 98. Cambridge University Press.

Wainwright, S. D. (1950). Ph.D. Thesis, London University.

WAinwright, S. D. \& Pollock, M. R. (1949). Enzyme adaptation in bacteria: Fate of nitratase in nitrate-adapted cells grown in the absence of substrate. Brit. J. exp. Path. 30, 190.

Wisseman, Jun., C. L., Smadel, J. E., Hahn, F. E. \& Hopps, H. E. (1954). Mode of action of chloramphenicol. I. Action of chloramphenicol on assimilation of ammonia and on synthesis of proteins and nucleic acids in Escherichia coli. J. Bact. 67, 662 . 